\title{
TRAINING FOR THE INNOVATIVE TEACHING AS A DETERMINANT OF THE PROFESSIONAL MOBILITY OF THE FUTURE TECHNOLOGY TEACHERS
}

\author{
Liudmyla Shevchenko \\ Vinnytsia Mykhailo Kotsiubynskyi State Pedagogical University, Ukraine
}

\begin{abstract}
The article deals with the professional mobility and readiness for the innovative teaching of future technology teachers as interdependent components. The purpose of the article is to study the organizational and methodological aspects of forming the professional mobility of future technology teachers in the context of preparation for innovation activities at Ukrainian Teacher Training Universities. Using the complex of theoretical and empirical research methods, the main organizational and methodical aspects of training were determined: the construction of the individual trajectory of study based on selected disciplines; the acquisition of new branches of activity; the forming of the complete conception of technological education and future innovative teaching; the introduction of innovative technologies (interactive discussions, motivational trainings, group forms of work, a problem-solving training, design and research activities, mixed learning, etc.); implementation of Information and communications technology (ICT), distance, Smart and hybrid education systems (e-learning resources, electronic educational and methodical complexes, Web services, individual and group projects based on Web quests and Blog quests); the monitoring of the readiness level for professional mobility; the strengthening of the consultative and coordinating function of teachers. The implementation of certain aspects expands the possibilities of optimizing the educational process not only at the level of formation of the readiness for professional mobility, but also at the level of the entire system of training future technology teachers to innovative teaching. It requires: creating conditions for continuous learning; the orientation of the final stages of pedagogical education to the formation of students' academic mobility; the rapid expansion of vertical and horizontal professional mobility ranges; the forming of future technology teachers' readiness and the ability to change the specialization, the place of work and even the profession, if necessary, or to master several specialties or training profiles at the same time.
\end{abstract}

Keywords: innovative teaching, mobility, professional mobility, technology teacher.

\section{Introduction}

The integration of Ukraine into the European and world community, the current level of the development of the society, the processes of modernization of the industrial, socio-economic and educational fields, the accelerated 
Shevchenko, 2020. Training for the Innovative Teaching as a Determinant of the Professional Mobility of the Future Technology Teachers

introduction of new technologies cause the emergence of a dynamic labor market, which creates not only certain requirements for specialists, but also initiates the emergence of new areas of professional activities.

In the context of the study of the formation of the professional mobility of future technology teachers, Ewald F. Zeer (2014) is relevant, who notes that the mobility is considered in vocational education in the following dimensions: "social and economic - as readiness and ability to adapt to rapidly changing labor market conditions; professional - as readiness and ability to rapidly and successfully master new machinery and technologies within the same profession, if necessary, to master the adjacent and new professions, as well as to carry out status moves in the space of the professional hierarchy; pedagogical innovations - as an activity in the creation, acquisition and use of innovations in the field of education" (Zeer, 2014, p. 35).

The fundamental works on developing the theme of social movements belong to the American authors (Blau \& Duncan, 1967; Lipset \& Bendix, 1954; Lipset \& Smelser, 1966), who cover issues related to the research, the use of terminology, the involvement of statistics to the processing of empirical information. Currently, the mobility is widely considered by researchers, particularly as: the process of the professional training and self-realization; the quality of personality; the readiness for the manifestation of any kind of mobility (social, professional, personal, psychological, etc.); the integrative ability, which provides the readiness to change professional status, career growth, etc.

We share the opinion of Blau \& Duncan (1967) who state that empirical research on mobility should be focused on analyzing the conditions that influence professional achievement and mobility within a particular society. The purpose of the article is to study the organizational and methodological aspects of forming the professional mobility of future technology teachers in the context of preparation for innovation activities at Ukrainian Teacher Training Universities.

The objectives of the research is to: 1) investigate the interconnections of preparation for the innovative teaching and professional mobility of future technology teachers; 2) analyze the results of the 4th year student survey after passing technological and preservice teaching practice; 3) identify and substantiate the organizational and methodical aspects of forming the professional mobility of future technology teachers in the context of preparation for innovative teaching.

\section{Methods}

To meet the objectives of the research, a theoretical complex was used (the analysis of pedagogical, scientific and methodological literature for comparison, 
the comparison of different views on the problem under study, the curricula and programmes with the aim of studying the peculiarities of the organization of the training of future technology teachers at Ukrainian Teacher Training Universities) and empirical (conversations, the 4th year student survey after passing technological and preservice teaching practice) research methods.

\section{Results and Discussion}

It has been determined (Shevchenko, 2013, p. 498) that innovative teaching is a complex formation, a set of various kinds of work with different goals and nature. The works correspond to the main stages of the development of innovative processes and aimed at creating and amending to the teacher's own work ethics. It involves developing, disseminating or using of educational innovations; has a complex, multi-faceted nature; combines scientific, technological and organizational measures. Innovating is a systemic activity aimed at implementing innovations based on the analysis, use and introduction of new scientific knowledge, ideas and approaches.

The article considers the innovative teaching of future technology teachers in two aspects: 1) improvement and development of the educational process through the development and implementation of new educational programmes, the allocation and development of new areas of activity and ideas, the creation and implementation of innovative projects, planning and implementation of pedagogical innovations to ensure improving the quality of education (ie, aimed at the result); 2) as a means of developing the abilities of future teachers by obtaining new competencies, expanding the horizons, changing the motivation both for innovative teaching and for teaching in general (ie, aimed at a person).

The relevance of the study of the formation of the professional mobility of future technology teachers in connection with the preparation for innovative teaching is conditioned by the need for preparation for work in various educational institutions (schools, colleges, vocational and non-technical educational institutions); conducting various types of training sessions (lessons, circles, studios, master classes, etc.); work with students of different age and social groups; solution of non-standard professional and technological tasks; interdisciplinary interaction and a combination of several specializations of technological education simultaneously; a quick reorientation to teaching new profiles and technology education specializations.

The survey of the 4th year 87 students (of the specialty 014 Secondary education, subject specialization 014.10) Labor studies and Technology after passing technological and preservice teaching practice has shown a number of problems, in particular, future technology teachers needed a considerable amount of time in order to adapt to educational activity during the practice 
Shevchenko, 2020. Training for the Innovative Teaching as a Determinant of the Professional Mobility of the Future Technology Teachers

(65\%), to work in a new team (67\%). Only $48 \%$ were satisfied with the chosen specialization; $38 \%$ were able to work in the related specialization of technological education; $72 \%$ were interested in obtaining additional specialization; $74 \%$ were ready to use ICT; $68 \%$ - for self-development of new knowledge; $55 \%$ - for self-fulfillment of technical and technological tasks; $42 \%$ - to perform applied tasks in related specialization; 58\% of respondents prepared an interdisciplinary project, Web or Blog Quest. Students noted that they encountered difficulties in the development of teaching and methodological support, the implementation of project technologies, the choice of the most reasonable pedagogical methods and tools, the development of lesson plans, the plans of pupils' projects, the organization of pupils' project activity (see fig. 1).

$64 \%$ of students indicated that they planned to work at educational institutions after studying and mentioned the possibility of career growth (61\%), higher social status (66\%), and well-being (58\%) as the reasons for their choices.

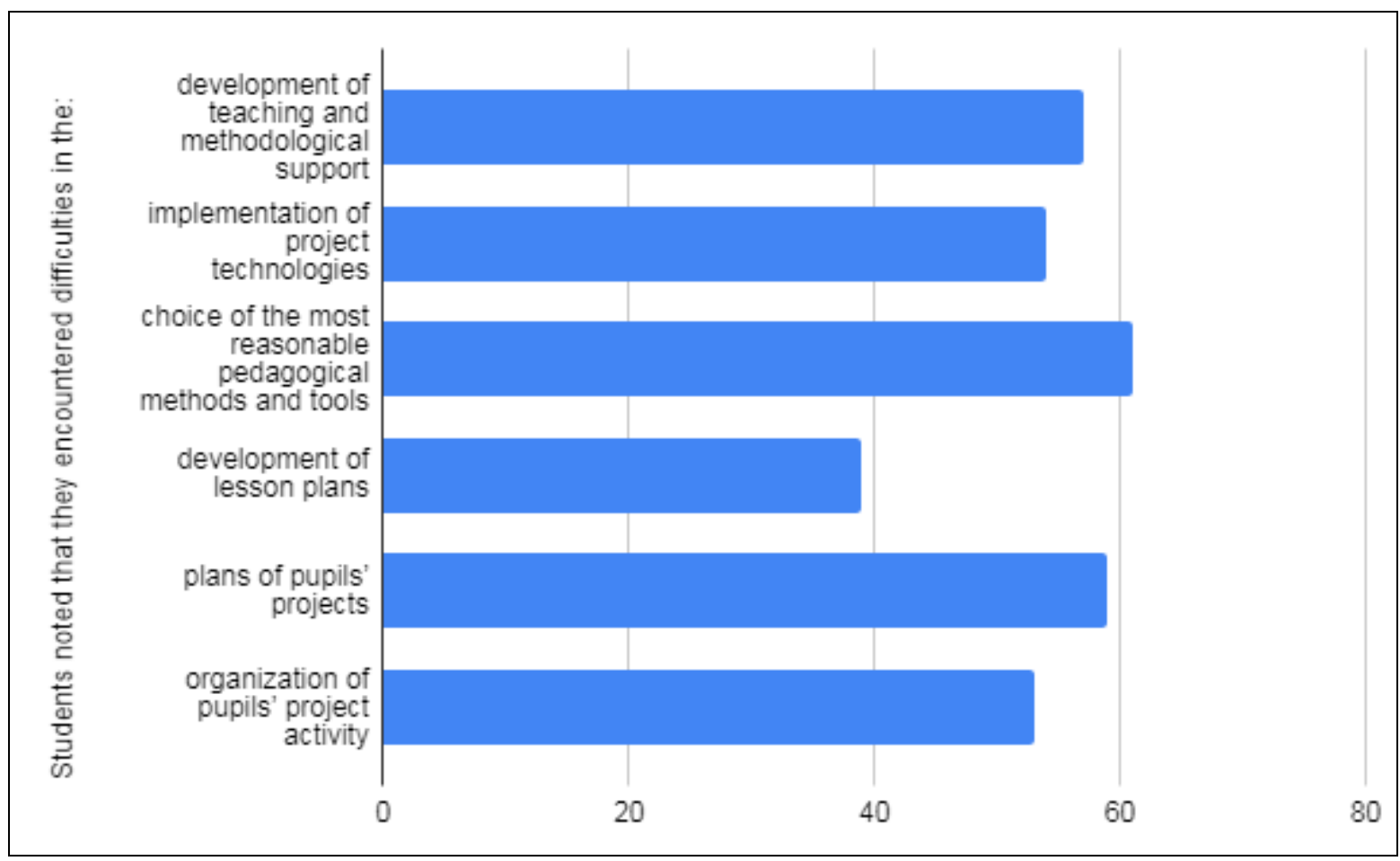

Figure 1 Diagnosis of difficulties experienced by students after completing the practice

The analysis of the results of the survey allowed us to conclude that the preparation of students for innovative teaching as a determinant of professional mobility should be considered as the readiness and ability of future technology teachers to work in conditions of rapid dynamic (horizontal and vertical) 
changes of professional functions within one professional activity and mastering of new specialties (specializations or profiles) in the context of the variability of the content of technological education. It is also important to analyze the readiness of future technology teachers for the innovate teaching on the basis of subject activity, value orientations, value self-determination, self-realization, self-improvement and subjective experience.

In general, the professional mobility of future technology teachers simultaneously characterizes: personality qualities (openness to the world, trusting people and trusting oneself, flexibility, efficiency, self-control, tolerance); personal potential, ability to apply the acquired knowledge, abilities and skills in different kinds of activities; abilities (reflection, self-regulation, self-determination, goal-setting, designing and management); capability (seeing and understanding the essence of changes, the variability of development, thinking constructively and productively, designing the necessary changes in the microsociety, group, solving problems, adapting to changes); readiness to move (expand, deepen) from one type and / or level of innovative teaching to another, whose result is the self-realization in life and profession, mastering of new competences; the process of a specialist's self-improvement as well as his/her both professional and living environment.

Analysis of the research on the problems of the formation of future teachers' professional mobility (Kadakin \& Zeynalov, 2016; Semenog, 2017; Syicheva, 2017; Villegas-Reimers, 2013), the peculiarities of its formation in the conditions of innovative education (Falyakhov \& Shatunova, 2015; Schwille, Dembele \& Schubert, 2007; Shelekhova, Blyagoz, Nagoev, \& Teshev, 2015), the generalization of one's own pedagogical experience. As well as the analysis of the curricula for the training of future technology teachers at Vinnytsia State Mykhailo Kotsiubynskyi Pedagogical University, National Drahomanov Pedagogical University, Ternopil National Volodymyr Hnatiuk Pedagogical University, Uman State Pavlo Tychyna Pedagogical University allowed us to identify the main organizational and methodological aspects of forming the professional mobility of future technology teachers:

- creating of conditions for maximum realization of potential opportunities of each student, which is achieved due to the nonlinearity and variability of curricula and programmes, and provides the possibility of constructing an individual trajectory of training based on our own choice of one or another selective discipline (analysis of curricula for preparing bachelors in the field of knowledge 01 Education, specialty 014 Secondary education, subject specialization 014.10 Labor studies and technology showed that each cycle of disciplines contains from 2 to 8 selective disciplines, each including up to 6 disciplines to choose from (for example, "Fibrous Fine Processing Practice" or "Practice on Technical Modeling and Design"; "Methodology of Profile 
Shevchenko, 2020. Training for the Innovative Teaching as a Determinant of the Professional Mobility of the Future Technology Teachers

Technology Training" (by specialization) or "Creative technologies of teaching”), or the disciplines of in-depth study of a certain specialization (for example, in-depth study of the discipline "Fundamentals of design": "Drawing and painting", "Ethnological sculpture", "Composition basics, history and arts", "Ethnological artistic Workshop"; "Informatics": "Special Informatics", "Algorithmic Programming Languages", "System Software”, "Computer Design", "Methodology of Computer Science Training”);

- focusing on the formation of fundamental knowledge and components of readiness for the innovative teaching (motivational, cognitive, activitytechnological and creative-reflexive) and their integration through interdisciplinary connections as the basis for the acquisition of new fields of activity (in the curricula of bachelor's training it is provided by the possibility of choosing a group of disciplines in-depth study of the Basics of Design, Informatics, Basics of Entrepreneurship, Basics of Automobile Transport, etc., future technology teachers join master courses by already selected one or 2-3 additional specializations (for example: "Fundamentals of Entrepreneurship", "Informatics", "Fundamentals of Design, Drawing", "Manager in Road Transport”, "Head of a Circle of Out-of-School Educational Institutions" etc.);

- forming a holistic conception of technological education and future innovative teaching that will prepare students for overcoming the psychological barriers that may arise while teaching new specializations or profiles of the educational branch of "Technology" or career growth (simultaneous study of disciplines "Pedagogy", "Psychology", "Theory and Technique of Technological Education" and professionally oriented disciplines ("Machine Science", "Technological Practicum", "Materials Science and Technologies for the Production of Structural materials" and others.);

- developing synergistic perception of the world, activation of conscious self-regulation of arbitrary activity of students through stimulation of their return to reflexive position, which will promote the development of decision-making skills and act in situations of uncertainty and unpredictability (through active involvement of students in interactive discussions, motivational trainings, group forms of work (for example: role and business games, "Debate", "Metaplan", "Industrial Failure", "Workshop of the Future", "Joint Project", "Information Search", "Carousel”, “Teachback", "Synectic brainstorming”), problem learning, project activity, research activities, work on mixed learning technologies, etc.);

- implementing of ICT, including distance, Smart and hybrid education systems (development, filling and use of e-learning resources, electronic educational and methodical complexes (for example: "Theory and methodology of labor and vocational training”, URL: http://ito.vspu.net/ENK/2011- 
2012/TIMTPN/index.htm; "Introduction to the specialty", URL: http://ito.vspu.net/ENK/2015-2016/vstup_pub/index.html; "Method of teaching Fundamentals of Information Technology", URL: http://ito.vspu.net/ ENK/MVOIT/index.html; "Electronic Document Workflow", URL: http://ito.vspu.net/ENK/2015-2016/komp_doc/index.htm; the involving students in independent educational activities by means of Web services (for example: "Innovation in education and science: main trends and perspectives" blog, URL: http://iito123.blogspot.com/); implementation of individual and group projects based on Web quests and Blog quests (for example: Web-quests "Turning Wood Technology”, URL: http://ito.vspu.net/ENK/2011-2012/TIMTPN/rob_stud_ 2012/StratiyGarmaziyGrutsak/golovna.html "Technology of making soft toys", URL: http://ito.vspu.net/ENK/2011-2012/TIMTPN/rob_stud_2012/2013/B/Brasls vez/index.html; "Technology of Handwriting of the Fabric', URL: http://ito.vspu.net/ENK/2011-2012/TIMTPN/rob_stud_2012/Rud/index.html; Blogs "Technology of Baking and Confectionery Production", URL: http://ito.vspu.net/ENK/2011-2012/TIMTPN/rob_stud_2012/2013/Punko/index. html, etc.)

- monitoring individual characteristics of the level of readiness for the professional mobility (the use of diagnostic techniques adapted for future technology teachers: How do you feel about your profession (Vershlovskyi \& Matyushkina, 2005, 80-82); Motivation of professional activity (Zamfir, modification of Rean, 2006); Questionnaire for the study of the development of cognitive and professional motives (Bakshaeva \& Verbitsky, 2019, 137-140); The level of self-actualization of personality. (CAT test, SAMOAL Questionnaire).

- strengthening the consultative-coordinating function of teachers.

Successful implementation of certain organizational and methodical aspects is possible only due to the functional unity of all elements of the pedagogical system, such as the organization of various types of practices, research work of students, coursework and diploma design, educational work, etc. The main load in this process falls on the system of normative and selective disciplines. Within the framework of normative disciplines the purposeful work on the formation and development of students' readiness for the professional mobility is being carried out, and as to the selective disciplines an individual trajectory of the preparation for the future innovative teaching and the formation of the professional mobility is being developed. One can take into account the subject experience, interests, inclinations, students' motives of students, and, thereby, increase motivation to professional self-realization exactly during studying selective disciplines rather than studying normative ones.

Implementation of certain aspects expands the possibilities of optimizing the educational process not only at the level of formation of readiness for the 
Shevchenko, 2020. Training for the Innovative Teaching as a Determinant of the Professional Mobility of the Future Technology Teachers

professional mobility, but also at the level of the entire system of training future technology teachers to innovative teaching. It requires: creation of flexible working plans, training and work programmes; the introduction of variational training modules, taking into account the specialization and modernization of education and technologies (for example, in the course "Theory and methodology of labor and vocational training”, the study of variation modules 'The methodology for studying labor education (computer technologies) in 1011 grades", "Methodology study of labor studies (design basics) in grades 1011", etc.; increasing the degree of student participation in planning their own trajectory of education; introduction of innovative pedagogical technologies and teaching tools.

The implementation of these provisions allows (especially for undergraduate and postgraduate students) to study not only the main educational programme, but also to get acquainted (and further study through cross-entry or second higher education) with educational programmes in related specialties or completely new ones, which is an essential prerequisite of academic mobility and successful preparation for the professional mobility.

\section{Conclusions}

Considering the above stated the professional mobility and readiness for the innovative teaching of future technology teachers is viewed as interdependent components: the innovative teaching is a determinant of the formation of professional mobility, and the professional mobility contributes to formation of readiness for the innovative teaching.

The analysis of the results of the 4th year students survey after technological and preservice teaching practice showed that preparation for the innovative teaching as a determinant of the professional mobility should be considered as the readiness and ability of future technology teachers to respond flexibly to ever-changing external (due to changes in the system of general secondary and vocational education, the educational field "Technologies") and internal (due to training or work in an innovative educational environment of the specific educational establishment) conditions.

Based on the analysis of the research into the problems of innovative education as a factor for the formation of the professional mobility of future teachers, the curricula for the training of future technology teachers in teacher training universities in Ukraine the following organizational and methodical aspects were defined: the construction of an individual trajectory of studying based on the independent students' choice of selected disciplines; the acquisition of new branches of activity; the formation of a holistic image of technological education and future innovative teaching; the application of innovative 
technologies; the introduction of ICT, distance, Smart and hybrid education systems; the monitoring of readiness for the professional mobility; the strengthening of the consultative-coordinating function of teachers.

Further definition and scientific substantiation require the development and implementation of variable and interdisciplinary programmes from various profiles and specializations of the educational field "Technologies", testing and experimental verification of certain aspects of the formation of the professional mobility, the development of a system for monitoring the readiness level for the professional mobility.

\section{References}

Bakshaeva, N.A., \& Verbitsky, A.A. (2019). Psihologiya motivatsii studentov [Psychology of student motivation] (137-140). Moscow: Yuryt Publishing House.

Blau, P., \& Duncan, O. (1967). The American Occupational Structure. N. Y., USA: Wiley.

Electronic Document Workflow, Electronic educational and methodical complexes. Retrieved from http://ito.vspu.net/ENK/2015-2016/komp_doc/index.htm.

Falyakhov, I., \& Shatunova, O. (2015). Formation of the Social-Professional Mobility of Students During Their Participation in the College Innovative Activity. The Social Sciences, 10, 926-929. DOI:10.3923/sscience.2015.926.929

Innovation in education and science: main trends and perspectives, Blog. Retieved from http://iito123.blogspot.com/

Introduction to the specialty, Electronic educational and methodical complexes. Retrieved from http://ito.vspu.net/ENK/2015-2016/vstup_pub/index.html

Kadakin, V., \& Zeynalov, G. (2016). Educational services market as a factor of formation of professional and conditions for its implementation. International Journal of Environmental and Science Education, 11, 8, 1721-1734. DOI: http://dx.doi.org/ 10.12973/ijese.2016.549a

Lipset, S., \& Bendix, R. (1954). Ideological Equalitarianism and Social Mobility in the United States. Transactions of the Second World Congress of Sociology, 11, 34-54.

Lipset, S., \& Smelser, N. (1966). Social Structure, Mobility and Development Chicago, USA: Aldine Publishers.

Method of teaching Fundamentals of Information Technology, Electronic educational and methodical complexes. Retrieved from http://ito.vspu.net/ENK/MVOIT/index.html

Motivaciya professionalnoj deyatelnosti (metodika K. Zamfir $\mathrm{v}$ modifikacii A. Reana) [Motivation of professional activity (method K. Zamfir, modification of A. Rean)]. Retrieved from https://smogendrr.ru/psybooks/rean-a-abordovskaya-n-vrozum-s-ipsixologiya-i-pedagogika-29-2

Schwille, J., Dembele, M., \& Schubert, J. (2007). Global Perspectives on Teacher Learning. Improving Policy and Practice. Paris, France: IIEP UNESCO.

Semenog, O. (2017). Forming Professional Mobility in the Process of Future Master Philologists' Training in Ukraine and Abroad. Comparative Professional Pedagogy, 6(4), 27-33. DOI: https://doi.org/10.1515/rpp-2016-0044

Shelekhova, L.V., Blyagoz, Z.U., Nagoev, A.V., \& Teshev, V.A. (2015). Innovative Education as a Factor of Professional Mobility Formation with the Students of 
Shevchenko, 2020. Training for the Innovative Teaching as a Determinant of the Professional Mobility of the Future Technology Teachers

Economic Specialties. Review of European Studies, 7(6). DOI: http://dx.doi.org/ 10.5539/res.v7n6p54

Shevchenko, L. (2013). Zastosuvannya innovacijny`x pedagogichny`x metody`k majbutnimy` uchy telyamy` texnologij [Application of innovative pedagogical methods by future technology teachers]. Sućas. inf. tehnol. innov. metod. navćanná pidgotovci fahivciv: metodol. teor. dosvid probl., 35, 457-502.

Syicheva, V. (2017). Problemyi formirovaniya professionalnoy mobilnosti bakalavrov [Problems of Formation of Bachelors' Professional Mobility]. Izv. Saratov Univ. (N. S.), Ser. Sociology. Politology, 17(2), 70-173. DOI: http://dx.doi.org/10.18500/1818-96012017-17-2-170-173.

Technology of Baking and Confectionery Production, Blog. Retrieved from http://ito.vspu.net/ENK/2011-2012/TIMTPN/rob_stud_2012/2013/Punko/index.html

Technology of Handwriting of the Fabric', Web-quests. Retrieved from http://ito.vspu.net/ENK/2011-2012/TIMTPN/rob_stud_2012/Rud/index.html

Technology of making soft toys, Web-quests. Retrieved from http://ito.vspu.net/ENK/20112012/TIMTPN/rob_stud_2012/2013/B/Braslsvez/index.html

Theory and methodology of labor and vocational training, Electronic educational and methodical complexes. Retrieved from http://ito.vspu.net/ENK/2011-2012/TIMTPN/ index.htm

Turning Wood Technology, Web-quests. Retrieved from http://ito.vspu.net/ENK/20112012/TIMTPN/rob_stud_2012/StratiyGarmaziyGrutsak/golovna.html

Uroven samoaktualizacii lichnosti. (Test SAT, Oprosnik SAMOAL) [The level of selfactualization of personality. (CAT test, SAMOAL Questionnaire)]. Retrieved from https://psycabi.net/testy/226-uroven-samoaktualizatsii-lichnosti-test-sat-voprosniksamoal

Vershlovsky, S.G., \& Matyushkina, M.D. (2005) Anketnyj opros v socialno-pedagogicheskom issledovanii [Questionnaire in socio-pedagogical research] (80-82). SPb.

Villegas-Reimers, E. (2003). Teacher professional development: An international review of the literature. Paris, France: IIEP, UNESCO.

Zeer, E.F. (2014) Mnogoznachnost fenomena "mobilnost” v professionalnom obrazovanii [Multitasking of the phenomenon of "mobility" in vocational education]. Sotsialnoprofessionalnaya mobilnost $v$ XXI veke: sb. mater. $i$ dokladov mezhdunarodnoy konferentsii (30-36). Ekaterinburg: izd-vo Ros. gos. prof.-ped. un-ta. 